3o-Ioo kg growing pigs and gestating-lactating sows. It results in a linear increase of $\mathrm{DBO}_{5}$, in relation to liveweight of growing pigs, whereas pollution (on liveweight basis) is enhanced for piglet and lowered for sows.

Food composition has a small influence except when fat $\left(\mathrm{DBO}_{5}\right.$ increased), fibre (DCO increased), $\mathrm{N}\left(\mathrm{NH}_{3}\right.$ increased) are added.

Management factors, including bedding with straw and washing of pens, have a wide influence on volume, dry matter and composition of solid/liquid wastes.

\title{
PRÉ-TRAitement des LISIERS De PORCS AVANT ÉPURATION BIOLOGIQUE
}

\author{
A. HAUBRY
}

Société Degremont, B. P. 46,92 Suresnes

\section{RÉSUMÉ}

L'étude rassemble les principaux résultats obtenus par tamisage sur vibro-séparateur et par centrifugation avec ou sans conditionnement au moyen de décanteuses continues.

Nous analysons essentiellement les rendements d'élimination en matières sèches, DCO et $\mathrm{DBO}_{5}$ et comparons les extractions de lisiers frais et lisiers âgés.

Le problème de la déshydratation des boues en excès provenant de l'épuration biologique de lisiers est également abordé.

\section{SUMMARY}

\section{SWINE, WASTES PRETREATMENT (BEFORE BIOLOGICAI, TREATMENT)}

This paper gives the main results obtained by sifting on vibrating separator and by centrifugation with or without conditioning, by means of continuous decanters.

We mainly analyse elimination rates of dry solids, $\mathrm{COD}$ and $\mathrm{BOD}_{5}$, and we compare the extractions of fresh and aged swine wastes.

We also examine the dehydration of activated excess sludge resulting from biological treatment. 